\title{
Analisis Pengaruh Teori Perilaku Terencana pada Niat Beli Produk Tabur Puja
}

\author{
Fhajri Arye Gemilang ${ }^{1}$, Allans Prima Aulia ${ }^{1}$, Silfia Riski $^{2}$ \\ ${ }^{1}$ Universitas Fort De Kock Bukittinggi, Indonesia \\ ${ }^{2}$ Universitas Putra Indonesia YPTK Padang, Indonesia \\ fhajri.gemilang@gmail.com, allans1406@gmail.com, silfia.riski@gmail.com
}

\begin{abstract}
The Purpose of this Research was To Identify the influence of Variabel in Theory of Planned Behaviour (Attitude Toward Behavior, Subjective Norm, Perceived Behavioral Control) toward Intention to Purchase of Tabur Puja Product (KPRI Kencana BKKBN Kab. Solok). The Sample of this Research was 115 Respondents of the cooperative member who has applied the loan application in Tabur Puja Products. Data analisyst used in this Research was Multiple Linear Regression. Hypothesits in this Research used T and F Test to test The Influnence Indepent Variable toward Dependent Variable. Result showed that "Attitude Toward Behavior" influenced significantly and positife to the intention to purchase of Tabur Puja Product. "Subjective Norm" influenced significantly and positife to the intention to purchase of Tabur Puja Product. "Perceived Behavioral Control" influenced significantly and positife to the intention to purchase of Tabur Puja Product.
\end{abstract}

Keywords: Tabur Puja, Theory Of Planned Behavior, TPB, Attitude Toward Behavior, Subjective Norm, Perceived Behavioral Control, Intention to Purchase.

\section{Pendahuluan}

Koperasi merupakan lembaga yang diakui eksistensinya di Indonesia dan dinilai sebagai Soko Guru atau sebagai Penyannga Utama / Tulang Punggung. Oleh karena itu koperasi difungsikan sebagai Pilar Utama dalam Sistem Perekonomian Nasional sehingga dapat memberikan peran yang aktif dalam mewujudkan kesejahteraan dan kemakmuran rakyat Indonesia.

Koperasi berperan di Indonesia adalah membantu permodalan Usaha-usaha Mikro Kecil dan Menengah (UMKM) yang tidak tersentuh oleh lembaga-lembaga Perbankan. Dalam kaitannya dengan pembiayaan setidaknya ada dua tipe kelompok UMKM, dimana Kelompok pertama adalah UMKM yang bankable yang ditandai dengan; Telah memiliki perangkat legalitas formal yang memadai; Manajemen yang lebih rapi; Akses pemasaran yang cukup; Penyajian informasi keuangan dapat diterima sesuai persyaratan bank teknis; Akses informasi dan pengetahuan terhadap produk perbankan cukup luas; dan Jaminan (collateral) dapat memenuhi persyaratan bank teknis.

Sedangkan Kelompok kedua adalah UMKM yang unbankable group, yang ditandai dengan; Belum memiliki perangkat legalitas formal yang memadai; Manajemen belum rapi; Akses pemasaran terbatas; Penyajian informasi keuangan belum memenuhi persyaratan bank teknis; Akses informasi dan pengetahuan terhadap produk perbankan terbatas. dan Membutuhkan peran koperasi sebagai penghubung dan mitra dalam membangun hubungan dengan perbankan".

Menurut Lembaga Pengembangan Perbankan Indonesia - LPPI (2015). "Data Badan Pusat Statistik memperlihatkan, pasca krisis ekonomi tahun 1997-1998 jumlah UMKM tidak berkurang, justru meningkat terus, bahkan mampu menyerap 85 juta hingga 107 juta tenaga kerja sampai tahun 2012 . Pada tahun itu, jumlah pengusaha di Indonesia sebanyak 56.539.560 unit. Dari jumlah tersebut, Usaha Mikro Kecil dan Menengah (UMKM) sebanyak 56.534.592 unit atau 99.99\%. Sisanya, sekitar 0,01\% atau 4.968 unit adalah usaha besar. 


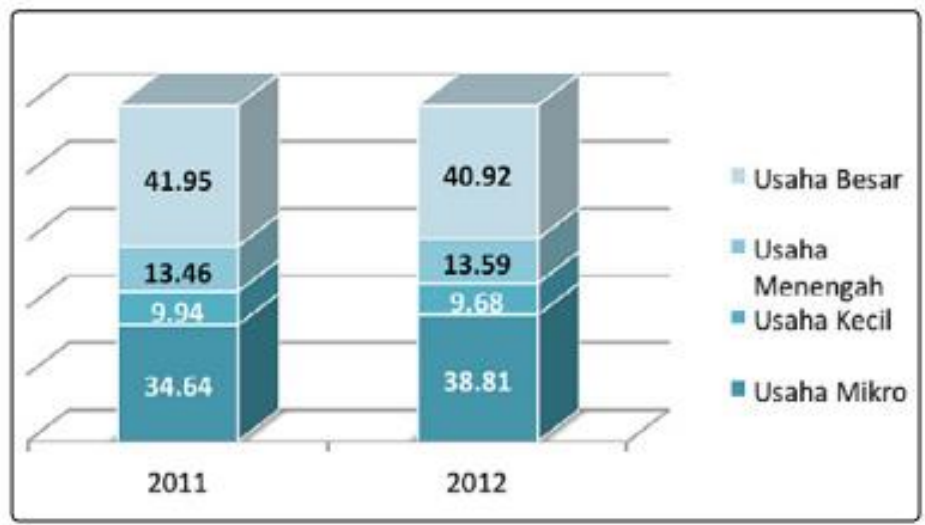

Gambar 1. Perkembangan Usaha Besar dan UMKM Tahun 2011 - 2012

Sumber: Kementerian Koperasi dan UMKM, 2014 dalam

Lembaga Pengembangan Perbankan Indonesia - LPPI (2015)

Data tersebut membuktikan, UMKM merupakan pasar yang sangat potensial bagi industri jasa keuangan, terutama bank untuk menyalurkan pembiayaan. Karena sekitar 60 - 70\% pelaku UMKM belum memiliki akses pembiayaan perbankan". Dari data tersebut potensi UMKM sebenarnya sangat besar untuk digarap oleh Perbankan, namun masih banyak UMKM yang belum tersentuh oleh Perbankan karena berbagai alasan. Disini terlihat bahwa terdapat Potensi yang cukup besar yang bisa digarap oleh Lembaga-lembaga Keuangan Penyedia Modal Kerja karena sektor ini masih belum maksimal dikelola oleh Lembaga Keuangan Perbankan, sehingga Peran Koperasi sangat dibutuhkan dalam menutupi hal tersebut.

Tabel 1. Data Kopeasi di Sumatera Barat

Berdasarkan Kelompok Usaha yang Dikelola Per 30 Juni 2015

\begin{tabular}{|c|c|c|}
\hline NO & Kelompok Koperasi & Koperasi (unit) \\
\hline 1 & 2 & 3 \\
\hline 1 & KUD & 413 \\
\hline 2 & Kop. Pertanian & 319 \\
\hline 3 & Kop. Perkebunan & 57 \\
\hline 4 & Kop. Peternakan & 22 \\
\hline 5 & Kop. Nelayan & 33 \\
\hline 6 & Kop.Kehutanan & 1 \\
\hline 7 & Kopti & - \\
\hline 8 & Kopra & - \\
\hline 9 & Kopinkra & 24 \\
\hline 10 & Koppontren & 74 \\
\hline 11 & Kopkar & 170 \\
\hline 12 & Kop. Angkt. Darat & 26 \\
\hline 13 & Kop. Angkatan Laut & 3 \\
\hline 14 & Kop. Angkt.Udara & 1 \\
\hline 15 & Kop. Kepolisian & 21 \\
\hline 16 & Kop. Serba Usaha & 593 \\
\hline 17 & Kop. Pasar & 60 \\
\hline 18 & Kop. Simpan Pinjam & 186 \\
\hline 19 & Kop. Angkutan Darat & 24 \\
\hline 20 & Kop. Angkutan Laut & 1 \\
\hline 21 & Kop. Angkutan Udara & - \\
\hline
\end{tabular}

\begin{tabular}{|c|c|c|}
\hline NO & Kelompok Koperasi & $\begin{array}{c}\text { Koperasi } \\
\text { (unit) }\end{array}$ \\
\hline 1 & 2 & 3 \\
\hline 22 & Kop. Angkutan Sungai & - \\
\hline 23 & Kop. Akt. Penyeberangan & 4 \\
\hline 24 & Kop. Wisata & - \\
\hline 25 & Kop. Telkom & - \\
\hline 26 & Kop. Perumahan & - \\
\hline 27 & K. B.P.R & 3 \\
\hline 28 & Kop. Peg. Negri (KPRI) & 765 \\
\hline 29 & Kop. Listrik Pedesaan & - \\
\hline 30 & Kop. Asuransi Indonesia & - \\
\hline 31 & Kop. Wanita & 114 \\
\hline 32 & Kop. Profesi & 6 \\
\hline 33 & Kop. Veteran & 19 \\
\hline 34 & Kop. Wredatama & 31 \\
\hline 35 & Kop. Pepabri & 19 \\
\hline 36 & Kop. Mahasiswa & 7 \\
\hline 37 & Kop.Pemuda & 6 \\
\hline 38 & Kop. Pertambangan & 4 \\
\hline 39 & Kop. Pdg. Kaki Lima & 6 \\
\hline 40 & Kop. Jamu Gendong & - \\
\hline 41 & Kop. Lainnya & 565 \\
\hline \multirow[t]{2}{*}{42} & KJKS & 174 \\
\hline & J u m l a h & 3.751 \\
\hline
\end{tabular}

Sumber: http://www.sumbarprov.go.id/details/news/5752 (data diolah)

Berdasarkan Tabel diatas, di Sumatera Barat terlihat bahwa Koperasi di Sumatera Barat sudah berada dalam jumlah yang cukup banyak dimana hal ini juga sejalan dengan pernyataan dari Kepala Dinas Kopeasi Prov. Sumbar, hal ini tentunya dapat mempermudah para pelaku UMKM khususnya Usaha Mikro dalam memperoleh akses permodalan. Dijelaskan bahwa terdapat sebanyak kurang lebih 3.751 buah koperasi yang ada Sumatera Barat yang diklasifikasikan kedalam 42 Jenis Koperasi berdasarkan Kelompok Usaha yang dikelola. 
Pada Prakteknya penulis melihat terdapat sebuah Koperasi di Kab. Solok yaitu Koperasi KPRI Kencana BKKBN Kab. Solok yang memiliki sebuah Unit Usaha yaitu bernama Unit Tabur Puja. Dimana Unit tersebut berfokus dalam Pengembangan Usaha Mikro dalam hal bantuan permodalan di wilayah Kab. Solok. Selain itu Unit ini juga berfokus pada pemberdayaan dan peningkatan kesejahteraan masyarakat kurabg mampu diwilayah Kerjanya tersebut. Koperasi ini Melalui Unit usahanya tersebut telah menggarap Segmen Usaha berupa pemberian Pinjaman Permodalan Usaha Bagi Segmen Usaha Mikro di Kab. Solok. Jika ditelisik Perkembagannya pada data Internal Perusahaan dalam 3 tahun terakhir, ditemukan bahwa terdapat peningkatan yang cukup signifikan dalam hal perkembangan asset dan perkembangan jumlah kredit yang disalurkan tiap tahunnya ke masyarakat, namun dari sisi perkembangan anggota tidak bertumbuh secara signifikan.

Maka dari itu hal tersebut sangat menjadi perhatian khusus bagi perusahaan karena dengan menurunnya perkembangan Jumlah Anggota akan menyebabkan penyaluran kredit yang ke setiap anggota yang ada harus diperbesar nilainya dikarenakan perusahaan harus mengejar pertumbuhan nilai kredit yang disalurkan. Jika ini terus dilakukan tanpa adanya usaha mengembangkan Jumlah anggota peminjam maka resiko kredit macet akan tinggi dihadapi koperasi karena koperasi ini bergerak pada pemberian modal tanpa jaminan/agunan sehingga koperasi hanya memberikan pinjaman modal dikisaran angka 1 (satu) juta Rupiah sampai dengan 4 (empat) Juta Rupiah. Bisa dilihat bahwa semakin kecil pertumbuhan angka jumlah anggota maka akan berdampak pada semakin besarnya nilai plafond yang bisa dipinjam oleh anggota karena perusahaan harus memperhitungkan pertumbuhan nilai kredit.

Melihat hal tersebut penulis ingin meneliti dampak dari penerapan Teori Perilaku Terencana atau biasa dikenal dengan Theory of Planned Behaviour dalam menilai niat untuk Membeli (mendaftar) Produk Tabur Puja, dimana akan dilihat 3 (tiga) buah variable yang dapat mempengaruhi dalam dalam Theory of Planned Behaviour yaitu Subjective Norm, Attitude Toward Behaviour, dan Perceived Behavioral Control sehingga mempengaruhi Intention To Purchase produk Tabur Puja pada Koperasi ini.

Ajzen, I. (2015) dalam penelitiannya menjelaskan "First described in 1985, the TPB is today one of the most popular social-psychological models for understanding and predicting human behavior. Briefly, in the TPB, the immediate antecedent of a particular behavior is the "intention" to perform the behavior in question". Ajzen menjelaskan bahwa Sejak pertama kali diperkenalkan pada 1985, TPB saat ini telah menjadi salah satu model sosial-psikologis yang paling popular yang digunakan untuk memahami dan memprediksi perilaku manusia. Secara Singkat pada TPB ini, yang mendahului langsung perilaku adalah "niat" untuk melakukan perilaku yang bersangkutan. TPB menunjukkan bahwa tindakan manusia diarahkan oleh tiga macam kepercayaan-kepercayaan yaitu kepercayaankepercayaan perilaku (behavioral beliefs), kepercayaan-kepercayaan normatif (normative beliefs), kepercayaan-kepercayaan control (control beliefs).

Menurut Rahmadanty, C., Kurniawati M (2015) Intensi dapat digunakan untuk memprediksi seberapa kuat keinginan individu untuk menampilkan tingkah laku dan seberapa banyak usaha yang direncanakan atau dilakukan individu untuk melakukan tingkah laku tersebut. Menurut Anoraga dalam Pratama, J.A.J, dan Japarianto, E. (2014) mendefinisikan niat beli merupakan suatu proses pengambilan keputusan yang dilakukan oleh pelanggan atas produk yang ditawarkan atau yang dibutuhkan oleh pelanggan.

Subjective Norms tidak hanya ditentukan oleh reference, tetapi juga ditentukan oleh motivation to comply. Secara umum, individu yang yakin bahwa kebanyakan referent akan menyetujui dirinya menampilkan perilaku tertentu, dan adanya motivasi untuk mengikuti perilaku tertentu, akan merasakan tekanan sosial untuk melakukannya. Sebaliknya, individu yang yakin bahwa kebanyakan reference akan tidak menyetujui dirinya menampilkan perilaku tertentu, dan tidak adanya motivasi untuk mengikuti perilaku tertentu, maka hal ini akan menyebabkan dirinya memiliki subjective norm yang menempatkan tekanan pada dirinya untuk menghindari melakukan perilaku tersebut (Ajzen, 2005).

Menurut Kotler dan Armstrong (2008), sikap adalah "Evaluasi, perasaan, dan kecenderungan dari individu terhadap suatu obyek yang relatif konsisten". Sikap menempatkan orang dalam kerangka pemikiran mengenai menyukai atau tidak menyukai sesuatu, mengenai mendekati atau menjauhinya.Selanjutnya, Linan \& Chen (2006), dalam penelitiannya menyatakan Attitude towards the behavior (Personal Attraction, PA) refers to the degree to which the individual holds a positive or 
negative personal valuation about being an entrepreneur. It would include not only affective (I like it, it makes me feel good, it is pleasant), but also evaluative considerations (it is more profitable, has more advantages).

Linan \& Chen (2006), Perceived Behavioral Control defined as the perception of the easiness or difficulty in the fulfillment of the behavior of interest. It is, therefore, a concept quite similar to perceived self-efficacy (SE) In all three instances, the important thing is the sense of capacity regarding the fulfillment of firm creation behaviors. Nevertheless, recent work has emphasized the difference between PBC and self-efficacy. PBC would include not only the feeling of being able, but also the perception about behavior controllability. That is, the extent to which performing it or not is up to the person.

Terdapat beberapa penelitian pendahulu yang telah diaplikasikan pada objek lain yang mendukung penelitian yang diangkat oleh penulis ini diantaranya, Temuan dari Penelitian yang dilakukan oleh Yogatama, L, A, M ,. (2013) ditemukan fakta bahwa "Attitude toward behavior merupakan faktor yang signigikan mempengaruhi intensi seseorang dalam menggunakan helm". Temuan dari Penelitian yang dilakukan oleh Lin \& Chen (2011) ditemukan hasil bahwa "subjective norms have strong influence on the unethical behavior intentions". Lalu keterkatian tentang ini juga diperkuat oleh Penelitian yang dilakukan oleh Burhanudin (2015) yang menyatakan bahwa "norma subjektif berpengaruh positif terhadap intensi mahasiswa menjadi pengusaha". Penelitian lain yang juga membahas tentang variabel yang sama dilakukan oleh Handayani, S. D (2011), menemukan bahwa "Subjective norm becomes the most influential variable for the behavioral intention on the hospital services".

Selanjutnya Temuan dari Penelitian yang dilakukan oleh Pratama, J.A.J, dan Japarianto, E. (2014) ditemukan bahwa "The result of this research shows that behavioral control influence simultaneously and partially towards customers will's to buy in SOGO department store in Tunjungan Plaza Surabaya". Penelitian lain yang juga sejalan adalah penelitian yang dilakukan oleh Yogatama (2011) Menyatakan bahwa persepsi terhadap pengendalian perilaku (percieved behavior control) merupakan faktor yang signifikan mempengaruhi intensi seseorang untuk menggunakan helm"

\section{Metodologi Penelitian}

Penelitian ini dilakukan dengan menggunakan pendekatan Kuantitatif. Penelitian ini dilakukan bertujuan untuk mengetahui hubungan Variabel-variabel dari Teori Perilaku Terencana / Theory of Planned Behaviour (TPB) dimana terdapat tiga dependent variabel (variabel bebas) didalamnya yaitu Attitude Toward Behavior (X1), Subjective Norm (X2), dan Perceived Behavioral Control (X3), Serta Variabel Independent (variabel terikat) yaitu Niat Beli / Intention to Purchase (Y). Responden dalam penelitian ini adalah Orang yang telah mengajukan permohonan kredit ke Unit Tabur Puja namun belum menjadi Anggota Peminjam produk Tabur Puja. Hal ini dikarenakan Permohonan kredit Mereka yang tengah diproses dan diverifikasi oleh Petugas Unit Tabur Puja. Maka dari itu Secara keseluruhan jumlah sample yang menjadi sampel penelitian ini adalah sebanyak 115 orang.

Penelitian ini bersifat deskriptif dan dianalisis secara kuantitatif dengan pendekatan parametrik. Teknik analisis yang digunakan adalah metode regresi linier berganda (Multiple Linear Regression Method). Analisis didasarkan atas nilai bobot kategori setiap pertanyaan yang menjadi pilihan jawaban responden.

Model ini dipergunakan untuk mengetahui hubungan tiga dependent variabel yaitu Attitude Toward Behavior (X1), Subjective Norm (X2), dan Perceived Behavioral Control (X3), Serta Variabel Independent yaitu Intention to Purchase (Y). Penelitian in menggunakan teknik pengumpulan data berupa penyebaran kuesioner kepada sampel yang ditetapkan.Regresi Linier Berganda dipilih karena jumlah variabel yang dihitung lebih dari dua variabel. Penghitungan regresi ini dilakukan dengan menggunakan bantuan komputer, yaitu paket program SPSS V.16.00. Bentuk umum persamaan regresi (Idris, 2010) adalah : 
Jurnal EKOBISTEK , Vol.10, SNo. 1. Januari 2021, Hal 7-14, ISSN : 2301-5268 | E-ISSN : 2527-9483 Copyright@2021 by LPPM VPI YPTK Padang

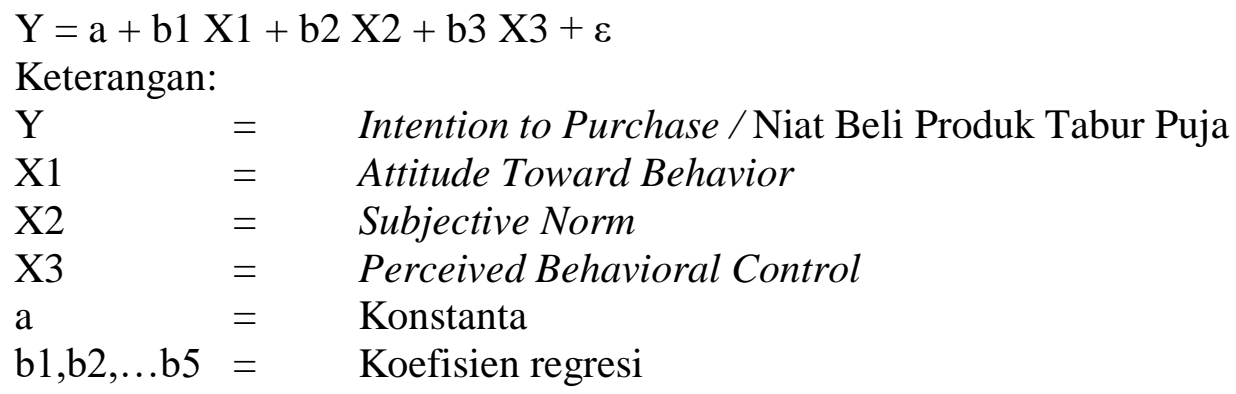

\section{Hasil dan Pembahasan}

Hasil Analisis Nilai Cronbach Alpha yang dihasilakan pada setiap variabel menunjukkan nilai yang lebih besar dari 0,60. sehingga semua variabel dinyatakan handal atau Reliabel untuk diteliti.

Sedangkan terkait Uji Normalitas dapat dilihat pada tabel berikut;

Tabel 2. Uji Normalitas Residual

One-Sample Kolmogorov-Smirnov Test

\begin{tabular}{|ll|r|r|r|r|}
\hline & & & & \multicolumn{1}{|c|}{ Kontrol } & \\
& & Sikap (X1) & Norma (X2) & Perilaku (X3) & Niat (Y) \\
\hline $\mathrm{N}$ & & 115 & 115 & 115 & 115 \\
Normal Parameters a,b & Mean & 24.42 & 12.35 & 20.15 & 24.09 \\
& Std. Deviation & 2.935 & 1.787 & 3.248 & 2.882 \\
Mbst Extreme & Absolute & .088 & .125 & .125 & .123 \\
Differences & Positive & .061 & .125 & .083 & .097 \\
& Negative & -.088 & -.118 & -.125 & -.123 \\
Kolmogorov-Smirnov Z & & .941 & 1.340 & 1.344 & 1.316 \\
Asymp. Sig. (2-tailed) & & .339 & .055 & .054 & .063 \\
\hline
\end{tabular}

a. Test distribution is Normal.

b. Calculated from data.

Normal P-P Plot of Regression Standardized Residual

Dependent Variable: Niat (Y)

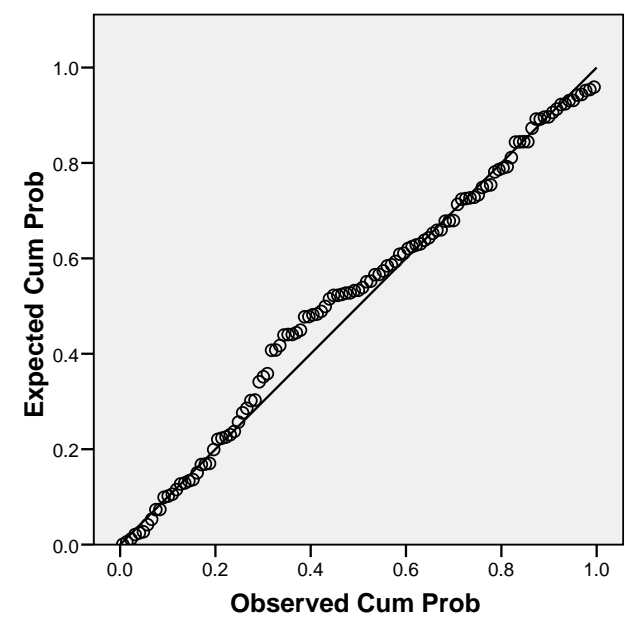

Gambar 2. Grafik Normalitas P-Plot

Berdasarkan Tabel dan Gambar yang dinyatakan diatas, terlihat bahwa data dalam sampel dalam penelitian ini terdistribusi dengan normal. 
Tabel 3. Uji Multikolinearitas Variabel Penelitian

\begin{tabular}{|l|c|c|}
\hline \multicolumn{1}{|c|}{ Variabel } & Tolerance & VIF \\
\hline X1 - Attitude Toward Behavior & 0,762 & 1,312 \\
\hline X2 - Subjective Norm & 0,577 & 1,255 \\
\hline X3 - Perceived Behavior Control & 0,897 & 1,115 \\
\hline
\end{tabular}

Berdasarkan tabel diatas dapat dilihat bahwa tidak terdapat adanya Multikolinearitas pada penelitian tersebut, karena dapat dilihat pada setiap variabel memiliki tingkat tolerance diatas 0,10 atau juga dapat dilihat pada nilai VIF yang berada pada kisaran nilai 1. Nilai VIF pada output menunjukkan keberadaan Multikolinearitas tidak signifikan, artinya tidak ada indikasi multikolinearitas dalam model. Ini ditunjukkan dengan nilai VIF untuk semua variabel Independen (X) kecil dari 10 dan Nilai Tolerance lebih besar dari 0.1 .

Sedangkan Uji heteroskedastisitas dalam regresi ini menggunakan Scatter Plot dengan bantuan SPSS.

$$
\text { Scatterplot }
$$

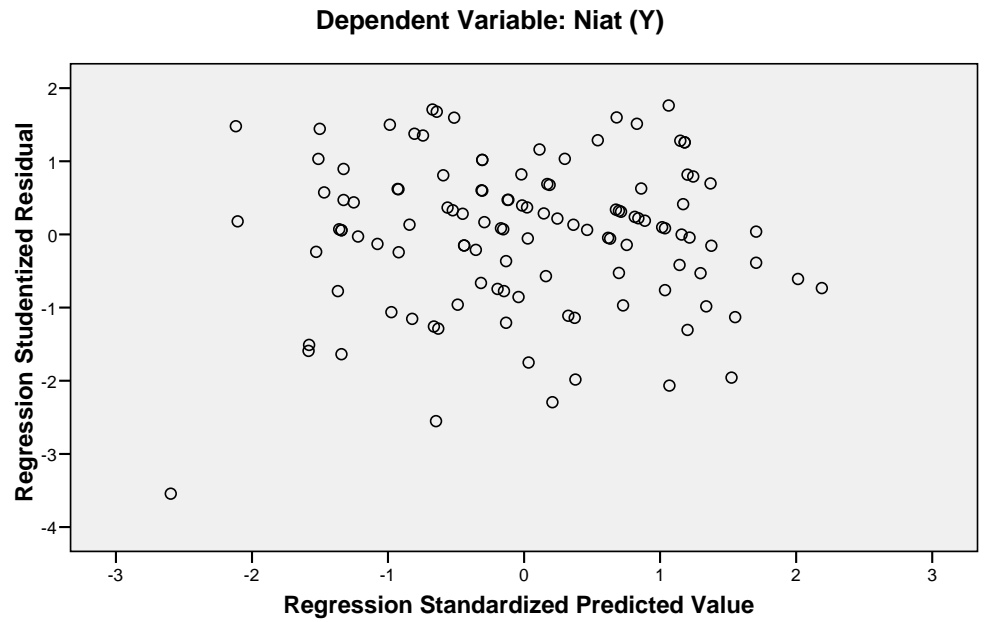

Gambar 3. Grafik Uji Heteroskedastisitas

Secara ideal, pola sebaran pengubah nilai dugaan (predicted value) dengan sisaan (residual) diharapkan membentuk pola acak disekitar nilai nol. Gambar diatas menunjukkan pola data yang acak, maka asumsi kehomogenan ragam (Heteroskedasitisitas) dapat dipenuhi.

Hasil pengolahan data penelitian dapat dilihat pada tabel berikut;

Tabel 4. Hasil Analisis Regresi Linier Berganda

\begin{tabular}{|c|c|c|c|c|c|c|c|c|c|c|}
\hline \multicolumn{11}{|c|}{ Coefficients } \\
\hline \multirow{2}{*}{\multicolumn{2}{|c|}{ Model }} & \multicolumn{2}{|c|}{$\begin{array}{l}\text { Unstandardized } \\
\text { Coefficients }\end{array}$} & \multirow{2}{*}{$\begin{array}{c}\begin{array}{c}\text { Standardized } \\
\text { Coefficients }\end{array} \\
\text { Beta }\end{array}$} & \multirow[b]{2}{*}{$t$} & \multirow[b]{2}{*}{ Sig. } & \multicolumn{2}{|c|}{$95 \%$ Confidence Interval for B } & \multicolumn{2}{|c|}{ Collinearity Statistics } \\
\hline & & B & Std. Error & & & & Low er Bound & Upper Bound & Tolerance & VIF \\
\hline & Sikap (X1) & .255 & .087 & .260 & 2.919 & .004 & .082 & .428 & .762 & 1.312 \\
\hline & Norma $(\mathrm{X} 2)$ & .299 & .140 & .185 & 2.129 & .035 & .021 & .577 & .797 & 1.255 \\
\hline & Kontrol Perilaku (X3) & .290 & .073 & .327 & 3.980 & .000 & .146 & .434 & .897 & 1.115 \\
\hline
\end{tabular}

Hasil pengolahan data tersebut dapat disubstitusikan kedalam persamaan regresi sebagai berikut;

$$
\mathrm{Y}=\mathrm{a}+\mathrm{b}_{1} \mathrm{X}_{1}+\mathrm{b}_{2} \mathrm{X}_{2}+\mathrm{b}_{3} \mathrm{X}_{3}
$$

Dimana hal tersebut jika diaplikasikan berdasarkan data-data penelitian yang ada maka dapat disimpulkan sesuai dengan berikut; 


$$
\mathrm{Y}=8.327+0,255 \mathrm{X} 1+0.299 \mathrm{X} 2+0,290 \mathrm{X} 3
$$

Dari persamaan regresi diatas, maka dapat dilihat bagaimana hubungan antara variabel bebas dan variabel terikat, yaitu Koefisien regresi untuk variabel Attitude Toward Behavior (X1) sebesar 0,255 dengan nilai signifikansi 0,004, maka dapat disimpulkan bahwa Variabel Attitude Toward Behavior (X1) ini memiliki pengaruh Positif terhadap Variabel Intention to Purchase (Y). Koefisien regresi untuk Variabel Subjective Norm (X2) sebesar 0,299 dengan nilai signfikansi sebesar 0,035, maka dapat disimpulkan bahwa Variabel Subjective Norm (X2) ini memiliki pengaruh Positif terhadap Variabel Intention to Purchase (Y). Koefisien regresi untuk Variabel Perceived Behavioral Control (X3) sebesar 0,290 dengan nilai signifikansi sebesar 0,000, maka dapat disimpulkan bahwa Variabel Perceived Behavioral Control (X3) ini memiliki pengaruh Positif terhadap Variabel Intention to Purchase (Y).

Terkait Uji F, maka kesimpulannya adalah variabel independen (X1, X2, dan X3) secara bersama-sama berpengaruh secara signifikan terhadap variabel dependen (Y). Terkait Uji T, Pada Variabel Attitude Toward Behavior (X1) terlihat bahwa nilai signifikansi adalah sebesar 0,004 < a (0.05), dimana hal tersebut menjelaskan bahwa H0 ditolak dan H1 Diterima sehingga variabel Attitude Toward Behavior (X1) berpengaruh signifikan terhadap Variabel Intention To Pruchase (Y). Pada Variabel Subjective Norm (X2) terlihat bahwa nilai signifikansi adalah sebesar 0,035 < a (0.05), dimana hal tersebut menjelaskan bahwa H0 ditolak dan H1 Diterima sehingga variabel Subjective Norm (X2) berpengaruh signifikan terhadap Variabel Intention To Pruchase (Y). Pada Variabel Perceiverd Behavioral Control (X3) terlihat bahwa nilai signifikansi adalah sebesar 0,000 < a (0.05), dimana hal tersebut menjelaskan bahwa H0 ditolak dan H1 Diterima sehingga variabel Perceiverd Behavioral Control (X3) berpengaruh signifikan terhadap Variabel Intention To Pruchase (Y).

Terkait Uji Koefisien Determinasi, Nilai adjusted R2 = 0,312 meunjukkan bahwa pemilihan variabel $\mathrm{X} 1, \mathrm{X} 2$, X3 dalam menjelaskan Variabel Y sebesar 31,2 persen, dan sisanya sebesar 68,8 persen dijelaskan oleh variabel-variabel lain diluar model penelitian.

\section{Kesimpulan}

Berdasarkan hasil penelitian yang dilakukan oleh peneliti tentang pengaruh Teori Perilaku Terencana / Theory of Planned Behaviour (TPB) dimana terdapat 3 variabel berupa Attitude Toward Behavior (X1), Subjective Norm (X2) dan Perceived Behavioral Control (X3) terhadap Variabel Niat Beli / Intention to Purchase (Y) Produk Tabur Puja, maka dapat ditarik kesimpulan sebagai berikut; Pertama, Variabel Attitude Toward Behavior (X1) berpengaruh signifikan dan positif terhadap Variabel Intention to Purchase (Y) pada Produk Tabur Puja. Pada Prakteknya di KPRI Kencana BKKBN Kab. Solok - Unit Tabur Puja, Pengaruh Variabel Attitude Toward Behavior (Sikap) terhadap niat menjadi anggota peminjam Tabur Puja adalah sebuah faktor yang penting yang harus diperhatikan oleh Perusahaan. Karena dalam penelitian ini Variabel ini memiliki pengaruh yang positif dan signifikan dalam menunjukkan niat seseorang untuk menjadi anggota peminjam Tabur Puja. Hal tersebut dapat digambarkan oleh beberapa pernyataan yang terdapat dalam penelitian yang memiliki nilai pengaruh yang cukup kuat seperti; Masyarakat akan lebih memilih produk Tabur Puja jika mereka mempunyai kemampuan dan kesempatan. Selanjutnya Masyarakat menilai bahwa menjadi anggota peminjam Tabur Puja merupakan suatu hal yang menarik bagi mereka. Indikator-indikator tersebut sudah menunjukkan nilai yang tinggi dalam menggambarkan niat menjadi anggota Tabur Puja.

Kedua, Variabel Subjective Norm (X2) berpengaruh signifikan dan positif terhadap Variabel Intention to Purchase (Y) pada Produk Tabur Puja. Dimana Prakteknya di KPRI Kencana BKKBN Kab. Solok Unit Tabur Puja, Pengaruh Variabel Subjective Norm (Norma Subjektif) terhadap niat menjadi anggota peminjam Tabur Puja digambarkan dengan baik melalui pernyataan-pernyataan dalam penelitian ini. Ini dibuktikan dengan setiap indikator pernyataan memiliki nilai yang baik dalam menggabarkan hubungan Norma Subjektif dengan Niat Menjadi Anggota Produk Tabur Puja. Pernyataan yang dinilai paling tinggi menggabarkan hubungan tersebut adalah tentang masyarakat menilai bahwa orang-orang penting yang berada dilingkungan mereka berpikir bahwa mereka sebaiknya menjadi anggota peminjam produk Tabur Puja. Selanjutnya keluarga dan teman-teman 
mereka juga menyarankan bahwa mereka sebaiknya menjadi peminjam produk Tabur Puja. Hal ini terjadi dikarenakan perusahaan menetapkan peminjaman di Tabur Puja adalah dalam bentuk kelompok-kelompok masyarakat yang saling berdekatan sehingga hal tersebut berdampak pada tingginya interaksi peminjam dengan lingkungan dan keluarga mereka.

Ketiga, Variabel Perceived Behavior Control (X3) berpengaruh signifikan dan positif terhadap Variabel Intention to Purchase (Y) pada Produk Tabur Puja. Pada Prakteknya di KPRI Kencana BKKBN Kab. Solok - Unit Tabur Puja, Pengaruh Variabel Perceived Behavioral Control (Kontrol Perilaku) terhadap niat menjadi anggota peminjam Tabur Puja digambarkan dengan 5 indikator pernyataan yang memiliki nilai bervariasi. Hubungan yang menggambarkan kedua variabel tersebut memiliki nilai tertinggi pada pernyataan "jika saya ingin, saya bisa dengan mudah menjadi anggota peminjam produk Tabur Puja". Ini membuktikan bahwa masyarakat bisa dengan mudah meminjam produk Tabur Puja disaat mereka memiliki keinginan untuk keperluan modal usaha. Dan dilanjutkan dengan pernyataan bahwa "selanjutnya terserah kepada saya apakah saya ingin menjadi anggota peminjam produk Tabur Puja atau tidak", Pernyataan tersebut menggambarkan bahwa sikap masyarakat dalam menentukan kemana mereka meminjam memang ditentukan oleh diri mereka sendiri.

\section{DAFTAR PUSTAKA}

LPPI. 2015. "Profil Bisnis Usaha Mikro, Kecil Dan Menengah (UMKM)". Kerjasama LPPI dengan BANK INDONESIA Tahun 2015.

Dinas Koperasi dan UMKM Sumatera Barat. 2015. DATA KOPERASI PER JENIS DI SUMATERA BARAT POSISI JUNI 2015. Diakses dari http://www.sumbarprov.go.id/details/news/5752 diakses pada Februari 2017.

Ajzen, I. 2015. "Consumer attitudes and behavior: The theory of planned behavior applied to food consumption decisions". Rivista di Economia Agraria, Anno LXX, n. 2, 2015: 121-138. DOI: 10.13128/REA-18003. ISSN (print): 0035-6190. ISSN (online): 2281-1559

Rahmadanty, C., Kurniawati M. 2015. Analisis Niat Perilaku Anggota Komunitas Hijabers Surabaya Dalam Menggunakan Tabungan Syariah: Perspektif Theory Of Planned Behavior. Jurnal Manajemen Teori dan Terapan. Tahun 8. No. 3, Desember 2015

Pratama, J.A.J, dan Japarianto, E. 2014. "Analisis Pengaruh Sikap, Subjective Norm dan Perceived Behavioral Control TerhadapPurchase Intention Pelanggan SOGO Department Store di Tunjungan Plaza Surabaya". Jurnal Strategi Pemasaran Vol. 2, No. 1, (2014) 1-7.

Ajzen, I., 2005, "Attitudes, Personality and Behavior, 2nd Edition”, McGraw-Hill Professional Publishing, Berkshire, GBR.

Kotler, P. dan Amstrong, G. 2008. Dasar-dasar Pemasaran, Edisi Kesembilan, Jilid 1, Jakarta: PT. Indeks Kelompok. Gramedia.

Liñán, Fr. and Chen, Y. 2006, "Testing the Entrepreneurial Intention Model on a Two-Country Sample", Departament d'Economia de l'Empresa.

Yogatama, Leo Agung Manggala. 2013. “Analisis Pengaruh Attitude, Subjective Norm, dan Perceived Behavior Control terhadap Intensi Penggunaan Helm Saat Mengendarai Motor pada Remaja dan Dewasa Muda di Jakarta Selatan". Prosiding PESAT 5.

Handayani, S. D. 2011. Theory Of Planned Behavior: Aplikasi PadaKonsumen Rumah Sakit. JURNAL MANAJEMEN \& BISNIS VoL 1 No.2 Moret 2011.

Idris. 2010. Aplikasi Model analisis Data Kuantitatif Dengan Program SPSS Edisi. Revisi III. Fakultas Ekonomi Universitas Negeri Padang. 